Applied Economics

\title{
Dimensions of civic activism and their effectiveness in exposing corruption: evidence from Italy
}

\author{
Nadia Fiorino, Emma Galli \& Rajeev K. Goel
}

To cite this article: Nadia Fiorino, Emma Galli \& Rajeev K. Goel (2018): Dimensions of civic activism and their effectiveness in exposing corruption: evidence from Italy, Applied Economics, DOI: $10.1080 / 00036846.2018 .1506086$

To link to this article: https://doi.org/10.1080/00036846.2018.1506086

曲 Published online: 31 Aug 2018.

Submit your article to this journal ๘

View Crossmark data $[7$ 


\title{
Dimensions of civic activism and their effectiveness in exposing corruption: evidence from Italy
}

\author{
Nadia Fiorino ${ }^{a}$, Emma Gallib and Rajeev K. Goele,

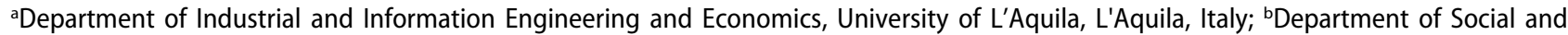 \\ Economic Sciences, Sapienza University of Rome; clllinois State University, USA; ${ }^{d K i e l}$ Institute for the World Economy, Germany
}

ABSTRACT

This article studies the influence of civic activism in exposing corruption across Italian regions. Using different dimensions of civic activism (including local and national newspapers, the internet, blood donors, and voter turnout), we make the distinction between active (media, internet, voters) and passive (blood donors) activism. Results show interesting different impacts of civic activism on corruption. In particular, voter turnout, blood donors, and national newspaper diffusion consistently increased exposure of corruption, while the internet and local newspapers showed opposite effects. Thus, local newspapers and the internet point to the possibility of media capture (influence) with regard to corruption exposure. The main findings hold following the substantial reforms in the nineties (called Mani Pulite).

\section{KEYWORDS}

Corruption; civic activism; newspapers; media; blood donors; voter turnout; internet; Italy

\section{JEL CLASSIFICATION} $\mathrm{K} 42 ; \mathrm{H} 70$

\section{Introduction}

Civic activism in democracies can be quite effective in improving governance and giving the populace a say in the matters of the state. Through organized protests, interactions through the media (letters to the editor in newspapers, internet blog posts, etc.), voter participation, the citizenry can keep the government in check and provide a useful oversight in performing the tasks of the people.

Given that activism can take various dimensions (e.g., newspapers readership, voting, volunteering, internet, etc.), and some activists work alone while others work in groups, the effectiveness of activism across different dimensions is not alike. Along another related dimension, some activists might be 'active' (e.g., participating in demonstrations, writing letters to the editor(s), blog posts), while others might be passive (e.g., volunteers - blood donors). Quantification of these effects is further complicated by the fact government's roles are quite diverse.

This article contributes by examining the relative effectiveness of different activism types on the governance quality, as captured by corruption. Activism could be effective in exposing corruption, although not all activists would be exposed to corruption or might have corruption on their radars. Civic zeal can help authorities in apprehending corrupt officials and activist citizens might themselves refuse to pay bribes. While media (both newspapers and the internet) facilitate activism via letters to the editor, blogs, etc., we also account for civic activism more directly by considering voter turnout and blood donors. The voluntary activities of voting in a democracy and blood donation can be seen as good measures of direct activism, while media can be seen as indirect activism. Viewed differently, blood donation can be considered passive activism (as opposed to voting or media participation).

There has been quite a bit of research on the causes of corruption in recent years (see, for example, Dimant and Tosato (2018)). Thus, we try to place this work in the context of the extant literature. Along one dimension, the relation between press freedom and corruption has intrigued researchers and policymakers for quite some time (see Bhattacharyya and Hodler (2015), Brunetti and Weder (2003), Camaj (2013), Freille, Haque, and Kneller (2007), Vaidya (2005)). Greater information flows via the media empower the public by increasing transparency 
(Bertot, Jaeger, and Grimes (2010)), enabling greater awareness of their rights and a heightened risk of exposure of illegal acts (of which corruption is one). However, these information flows may be manipulated by vested interests, especially when information providers are concentrated or when the government has a control over media all of which signify a lack of press freedom. This issue has gained added attention in recent years with the advent and popularity of new mediums like the internet.

Another related and important aspect is that not all media types are qualitatively alike and that might affect their efficacy in terms of impacts on corruption. For instance, print media like newspapers have limited geographic reach and the information flow is uni-directional (i.e., from the publisher to the reader). This information can be 'doctored' when there is a lack of competition in the newspaper market or when the newspapers are owned by the government (or by political parties), (see Di Tella and Franceschelli (2011), Djankov et al. (2003), Mullainathan and Shleifer (2005)). Further, the dichotomy between national and regional (or local) newspapers enables them to cater to different market segments by focusing on varying size and scope of coverage. In the context of corruption, this dichotomy might enable them to disproportionately affect local (or petty) corruption or national (or grand) corruption. ${ }^{1}$

A significant development in recent years has been the advent of the internet. The internet has been nothing short of a game changer in the market for information flows (Agostino (2013), Yang (2009)). First, the internet is free of geographic limitations as a website located in a remote corner of the world can be accessed around the world. Second, the internet not only enables the supply of information (as do newspapers), but it also enables the production of information when readers can write comments or blog posts (and this is unlike traditional newspapers). ${ }^{2}$ Finally, as a result of the above two features, the internet enables a democratic market for information flows whereby it is relatively easy to be a supplier and a producer of information (e.g., hosting a website and being a blog contributor). Again, this can affect corruption (see Andersen (2009), Goel, Nelson, and Naretta (2012)).

While the main focus of this work is on examining the relative efficacy of activism types on corruption exposure, the media-corruption-civic activism nexus is examined via some novel angles. Various dimensions are considered dealing with (i) media types; (ii) newspaper competition and diffusion (readership); and (iii) geographic scope. In particular, we consider two media types: newspapers and the internet, while accounting for differences in competition and diffusion at the national and regional levels. National newspapers might have greater clout and might focus more on grand corruption, while local newspapers are better attuned to local issues and can better address petty corruption. Conversely, local newspapers might be more prone to be captured by vested interests. The internet, on the other hand, is relatively free of jurisdictional limitations and is more democratic. Furthermore, as discussed above, voter turnout and blood donations provide good measures of civic activism that would influence corrupt acts coming to light. For instance, greater voter turnout in elections is likely to make politicians and other elected officials more responsive to the electorate and more vigilant in fighting/exposing corruption. Our data from Italian regions uniquely enables us to take these qualitative differences into account in studying the role of media and civic activism on corruption exposure in Italy.

The measurement of a clandestine and illegal activity like corruption is always problematic and has to be proxied by some measure. Country-level studies mostly use indices of corruption perceptions based on surveys, while single nation studies sometimes have access to surveys of corruption experiences or data on prosecutions (see Belousova, Goel, and Korhonen (2016), Goel and Nelson (2011), Olken (2009)). Given that actual corruption is nearly impossible to measure (with the moral hazard facing participants in corrupt acts to reveal their participation plus the monetary and non-monetary forms of bribes (see Donchev

\footnotetext{
${ }^{1}$ Note that we use the terms local and regional interchangeably to denote subnational levels.

${ }^{2}$ In this manner, the internet has some overlap with 'traditional' media but it is broader in other respects.
} 
and Ujhelyi (2014); also Goel and Nelson (2010)), we have regional Italian time series data on corruption prosecutions. ${ }^{3}$ Prosecutions are invariably broader than convictions (as not all prosecuted for corruption are convicted) and given the possibility of hidden (unrevealed) corruption, we call the prosecutions 'exposed corruption'. 4

The problem of corruption is significant worldwide and corruption remains a significant issue in Italy. Italy has grappled with the problem of corruption over the years. According to the 2015 Corruption Perceptions Index, Italy was ranked 61 st out of 168 nations, and it was also somewhat in the middle in other measures of corruption (https://www.transparency.org/country/\#ITA; also see Petrarca and Ricciuti (2013)).

The subnational Italian data enables consideration of some interesting regional differences. Italy has 20 regions that are geographically, culturally, historically and administratively somewhat distinct. For instance, two of the twenty are islands (Sardinia and Sicily), which would impact information flows (although less so via the internet). Further, administratively, five of the 20 regions are autonomous with a qualitatively different relationship with the central government. This would likely affect corruption and corruption exposure differently, and our sub-national data enables us to take these into account.

Key questions addressed in this research are the following:

- What is the effect of civic activism on corruption exposure?

- Are the influences of activist activism the same as those of passive activism?

- Are the effects of newspapers and the internet similar in terms of exposing corruption?

- Do regional and national newspapers have similar effects on corruption exposure?

These questions contribute to the extant literature while also having some policy value. Next, we discuss related literature in more detail and outline the estimated model.

\section{Literature and model}

\section{Literature}

A number of strands of broader literature are related to this study. First, while the research on determinants of corruption is a quite crowded field in recent years, there is still room for studies on individual nations that use sub-national data (literature surveys can be found in Aidt (2003), Dimant and Tosato (2018), Lambsdorff (2006) and Seldadyo and De Haan (2006)). We are focusing on the determinants of corruption exposure via civic activism differences.

Second, the literature examining the media freedom - corruption nexus has mainly used cross-country data and mostly found the influence to run from greater press freedom to lower corruption (see Brunetti and Weder (2003), Chowdhury (2004), Freille, Haque, and Kneller (2007)). We are able to consider qualitatively different aspects both within (regional versus national newspapers) and across (internet versus newspapers) media. Within the substantial literature on the economics of corruption, we focus on the subfield of media and corruption, with attention to Italy. In particular, with regard to the broader literature on corruption determinants, useful surveys can be found in Aidt (2003), Dimant and Tosato (2018), Lambsdorff (2006), Seldadyo and De Haan (2006), Serra (2006) and Svensson (2005), with Paldam (2002) and Treisman (2000) being well-cited and rather comprehensive cross-country studies. Given the many potential drivers of corrupt activity, the literature surveys and related sensitivity analyses enable us to identify key drivers of corrupt activity in Italy.

Third, some scholars have focused on corruption in Italy, but none have examined the role of media in any detail (see Corrado and Rossetti

\footnotetext{
${ }^{3}$ Golden and Picci (2005) provide an interesting measure where they proxy corruption as the difference between funds spent for public works and physical public goods. The authors themselves admit that the resulting measure might also be picking up government inefficiency, which might not necessarily be related to corruption. Besides, the Golden-Picci Italian regional corruption index is available for a single year - 1997.

${ }^{4}$ Although, many studies in the literature frequently denote available corruption prosecutions or convictions as corruption, implicitly assuming no measurement/detection discrepancies (see Del Monte and Papagni (2007), Goel and Nelson (2011)). Goel and Nelson (2014) study the effect of whistleblower laws on corruption exposure in the United States.
} 
(2018), Del Monte and Papagni (2007), Di Vita (2011), Picci (2006)).

The strand of the literature focusing on the media influence on corruption recognizes the possibility of a bi-directional relationship and the possibility of media capture (Besley and Prat (2006), Djankov et al. (2003), Mullainathan and Shleifer (2005)). In a broader context, the literature also empirically finds the direction of causality from greater media freedom to lower corruption (Brunetti and Weder (2003), Camaj (2013), Freille, Haque, and Kneller (2007), Svensson (2005)). ${ }^{5}$ The main underlying rationale is that media poses a threat of exposure for bribe takers and bribe givers, while also prodding lawmakers and enforcement agencies to be more vigilant against corruption. However, the diffusion of different media across various subnational regions in a country is something that has not been addressed and forms the key contribution of the present work.

With regard to corruption-media nexus for Italy, perhaps the closest study to the present work is the earlier work by Del Monte and Papagni (2007) who examine the drivers of corruption across Italian regions. However, that study does not focus on the role of media in affecting corruption. The authors find evidence of nonlinearities in the relation between Italian corruption and some of its determinants. On the other hand, with respect to activism-corruption, Corrado and Rossetti (2018) recently examined a broader measure of crime (i.e., crimes committed by public officials against the public administration and prosecuted) and the impact of volunteerism for the years 2000-2011. The present work, in contrast, considers the effect of various forms of activism on corruption exposure. Other than that, Di Vita (2011) has a case study of corruption in Sicily, and Della Porta and Vannucci (2007), Petrarca (2014) and Rhodes (1997) provide some institutional and historical details from the Italian context. While we consider some relevant institutional aspects, we are unable to account for others that are mainly qualitative and difficult to quantify.

Central to all this is the ability to adequately measure corruption. Corruption is inherently a clandestine activity, with perpetrators (i.e., bribe takers and bribe givers) facing moral hazard issues with regard to disclosure of their participation in corrupt acts. Tracking corruption is further complicated by the various ways in which corrupt transactions are undertaken, some of which are in-kind (non-cash), (see Goel, Budak, and Rajh (2013)). Two ways to capture corrupt activity include surveys of corruption perceptions and data on corruption prosecutions (or corruption exposure), (see Belousova, Goel, and Korhonen (2016), Goel and Nelson (2011), Olken (2009)). Both approaches have some plus and minus points. Surveys generally cannot be conducted at regular intervals and survey respondents might not have first-hand experience with corruption (see Bertrand and Mullainathan (2001) for a broader related discussion). However, survey respondents are less likely to face moral hazard disclosures issues discussed above. Corruption prosecutions are 'hard' evidence of corrupt activity and offer ready time series data, but they might be undercounting corrupt activity if the prosecution is lax. We use available time series on corruption prosecutions across Italian regions to capture corruption exposure.

Given the above discussion, we come up with the following testable hypothesis

H1: Active activism would be more effective at exposing corruption than passive activism, ceteris paribus.

The next section provides some institutional details about Italy that will lead to a formal model to empirically test this hypothesis.

\section{Institutional details about Italy}

Italy is divided into 20 regions that are geographically, culturally and administratively quite diverse; five regions enjoy a special statute (Regioni a Statuto Speciale, or RSS) because of their multilingual status, foreign border location or some secessionist movements (Friuli-Venezia-Giulia, Sicilia, Sardegna, Trentino Alto Adige comprising the two Autonomous Provinces of Trento and

\footnotetext{
${ }^{5}$ Kalenborn and Lessmann (2013) point out that democracy and press freedom may be intertwined (also see Bhattacharyya and Hodler (2015)).
} 
Bolzano, and Valle d'Aosta), while 15 regions (Piemonte, Lombardia, Veneto, Emilia-Romagna, Toscana, Liguria, Marche, Umbria, Abruzzo, Lazio, Molise, Basilicata, Campania, Puglia, and Calabria) are characterized by an ordinary statute (Regioni a Statuto Ordinario, or RSO).

Since the mid-1990s a gradual process of fiscal decentralization, accomplished through several legislative acts and a constitutional reform in 2001, occurred and was aimed at increasing the fiscal autonomy of the regional governments. The latter have major responsibility for some sectors such as healthcare, social services, environment, local transportation, housing, culture and tourism, and differences in competencies between the RSOs and RSSs have been reduced.

During the 1990s a massive judicial investigation against corruption, known as Mani Pulite (Clean Hands) or Tangentopoli, involved many Italian politicians for alleged bribery (see Della Porta and Vannucci (2007)). The scandal, highlighted in the media by newspapers, deeply affected the Italian political scene to the point that important changes were made to increase political accountability of national and regional representatives.

Newspapers are a vital source of political information in Italy. As matter of fact, starting from the mid-1980s, the Italian newspaper industry experienced both legislative and technological innovations. While the latter decreased the production costs and greatly facilitated the expansion of the supply of newspaper information, a few laws issued in 1981, 1987 and 1990 introduced some constraints to the property and financial concentration and enlarged the channel of public contributions to the newspapers. Moreover, the increase in the advertising sponsorships in those years made newspapers financially more autonomous (Valentini (2012)). All of these events resulted in an expansion of the supply of the local newspapers.

However, the national Italian news market is highly concentrated and subject to capture by political interest groups, while the market for local news exhibits wide variation in the extent of newspaper competition both across and within regions (on these aspects, see Drago, Nannicini, and Sobbrio (2014)). ${ }^{6}$ The change in media competition over time via entry and exit of newspapers as well as regional differences are captured in our analysis.

Furthermore, other dimensions of activism, including voter participation, blood donations, and internet usage also differ across regions and are likely to impact corruption exposure.

\section{Model}

A few methodological considerations are in order before setting up the estimated model. With regard to media influence, while some scholars have recognized, at least theoretically, the possible simultaneity between media freedom and corruption (see Besley and Prat (2006)), a number of studies have shown the direction of causality to be from greater press freedom to lower corruption (Brunetti and Weder (2003) and Freille, Haque, and Kneller (2007)). Nevertheless, we take account of simultaneity issues in all estimations.

The estimated model takes the following general form (with subscript i denoting an Italian region and $t$ a year). The annual data employed spans 1980 to 2010 (details are provided below).

Corruption $\left(\mathrm{CORR}_{\mathrm{it}}\right)=\mathrm{f}\left(\right.$ Civic activism $_{\mathrm{imt}}$, Economic prosperity $\left(\mathrm{GDP}_{\mathrm{it}}\right)$, Government size $\left(\right.$ GovtSize $\left._{\mathrm{it}}\right)$, Region size $\left.\left(\mathrm{POP}_{\mathrm{it}}\right)\right) \ldots(1)^{7}$

$\mathrm{i}=1,2,3$

$\mathrm{t}=1980, \ldots, 2010$

$\mathrm{m}=$ BloodDON, Voters, NatReader,

LclReader, NatNews, LclNews, Internet

The dependent variable (CORR) is the annual number of corruption prosecutions by Italian regions from 1980 to 2010 (weighted by regional population). As is well-known, clandestine illegal acts like corruption are hard to measure and such acts have been exogenously proxied by either incidence or perceptions data, both of which are imperfect (see Goel and Nelson (2011), Olken (2009)). Corruption prosecutions would underestimate prevailing corruption to the extent some

\footnotetext{
${ }^{6}$ At local level, large publishing houses such as Gruppo editoriale l'Espresso, Caltagirone editore in the Central and Southern regions, Poligrafici editoriale coexist with several small publishing houses like Athesis, Athesia Druck, Domenico San Filippo editore, I'Unione editoriale, Sesaab, S.E.C.

${ }^{7}$ Although the internet may be viewed as part of the media, we consider it separately in equation (1) due to its qualitatively different nature. Further, we denote newspaper usage (circulation) as media diffusion and newspaper prevalence as media competition.
} 
corrupt activity is not detected and/or not prosecuted. Low prosecutions might imply low levels of corruption or an inability to detect/prosecute all corruption. Alternately, corruption prosecutions can be argued to partly capture the strength of enforcement. Corruption prosecutions or exposed corruption data has the virtue that it is based on 'hard' evidence and not on surveys of perceptions about corruption, where survey respondents might not have personal experience with corruption. Nevertheless, corruption convictions in the United States have widely been used to denote state-level corruption in the United States (see Campante and Do (2014) and Goel and Nelson (2011) for a listing of related studies). Further, we use corruption incidence or prosecutions as that is the only time series available across Italian regions and denote them as corruption exposure.

Turning to the main determinant of interest, i.e., civic activism, we analyze several aspects. First, we consider two different media types - newspapers and the internet. As discussed above, the two forms are qualitatively different in terms of their geographic reach, in their ability to enable government control and in their ability to allow for two-way communication between the producers and consumers of information. ${ }^{8}$ Second, we consider both regional and national newspapers, with this distinction having a bearing upon the type of corruption exposed. National newspapers are likely to focus more on grand corruption, whereas local or regional newspapers would tend to focus more on petty corruption. Third, we utilize both the number of newspapers (NatNews and LclNews, respectively) and their diffusion or usage (NatReader and LclReader, respectively), which enables us to address not just the flow of information (via media competition) but also its usage (via diffusion). ${ }^{9}$ The number of newspapers can be seen as capturing competition in the market for information production and is a direct measure of press freedom (as opposed to composite indices).
The time series dimension of the sample enables us to capture the entry and exit of newspapers. On the other hand, the media diffusion measures capture the broader related aspects of media impact or efficacy. We follow Petrarca (2014) and classify newspapers as national if they are diffused in all regions; otherwise, they are considered local. ${ }^{10}$ Fourth, voter participation (Voters) is considered and it would lead to corruption exposure, especially political corruption or corruption tied to otherwise elected bureaucratic posts. Greater voter participation is a sign of responsive/responsible democracy. Finally, blood donors (BloodDON) capture other forms of volunteerism (or positive social externalities) and can be seen as addressing passive activism referred to in Hypothesis 1. While media and other forms of activism could have similar effects, media is subject to capture and market structure considerations.

The other controls for corruption exposure include economic prosperity (GDP), government size (GovtSize), and region size (POP). ${ }^{11}$ These determinants are routinely used as controls in studies of corruption causes (see Lambsdorff (2006) and Seldadyo and De Haan (2006)).

Economic prosperity is associated with better checks against corruption and heightened opportunity costs of illegal acts. This factor has been widely shown to lead to lower corruption (see Serra (2006)). With regard to corruption exposure, greater economic prosperity might be correlated with a better-equipped government infrastructure that would aid exposure. The influence of government size is related to a bloated government leading to greater rent-generating and rent-seeking opportunities (see Shleifer and Vishny (1993) and Rose-Ackerman (1999)), although a larger government at times might be a result of heightened effort to fight illegal activity. A larger government is likely to have better and more enforcement that would assist corruption exposure. However, exposing corruption in a large

\footnotetext{
${ }^{8}$ See Goel, Nelson, and Naretta (2012) and Picci (2006) for use of alternate internet-based measures in corruption research. Further, some studies have used broader indices capturing e-government and found the influence of e-government on corruption to be negative (Andersen (2009)).

${ }^{9}$ See Di Tella and Franceschelli (2011) for an interesting study capturing the influence of political structure on newspaper information flows in Argentina (also see Rizzica and Tonello (2016)). Reinikka and Svensson (2005) provide some evidence from Uganda.

${ }^{10}$ The major national newspapers are: Avvenire, II Corriere della Sera, II Giornale, II Messaggero, II Tempo, Italia Oggi, Libero, II Manifesto, La Repubblica, II Sole 24 Ore, La Stampa and L'Unità.

${ }^{11}$ One other determinant that may be relevant is some measure of enforcement (e.g., police or judicial employment). Unfortunately, such information is not publicly available for Italy. Further, Priks (2011) and others have noted that enforcement agencies might themselves be corrupt.
} 
government machinery might not be easy when responsibilities are intertwined, making it difficult to pin blame.

Finally, region size (POP) is included to capture both the competition for rents and the monitoring ability of the government. Smaller regions, ceteris paribus, might have smaller scale projects reducing the potential benefits of bribery but monitoring might be relatively easy. More populous regions might also have keener competition for rents. Conversely, corruption might be harder to detect and prosecute in larger regions and there might be greater exposure of corrupt acts in smaller regions via word of mouth or other informal means. ${ }^{12}$ Next, we turn to a discussion of the data used and the estimation procedure employed.

\section{Data and estimation}

\section{Data}

We use a dataset which collects information on news media, politico-institutional and socio-economic features for 18 of the 20 Italian regions during the period 1980-2010. ${ }^{13}$ The panel nature of our data is useful with regard to corruption, as a single year (such as in cross-sectional studies) could have large blips (lumpiness) associated with a high profile corruption case or greater vigilance associated with election years.
Given that the dependent variable is corruption prosecutions, it is technically measuring exposed corruption, rather than overall corruption. The literature, however, frequently, takes prosecutions to signify corruption (see, for example, Goel and Nelson (2011)). The notion of corruption exposure is especially relevant in a study like this with its focus on the role of media and civic activism.

The data employed are mainly from Italian official sources and in many instances they exhibit considerable variation across individual regions. For instance, the number of national newspapers, capturing press freedom or media competition, ranged from 11 to 17 , with a mean of about 15 . Given its relatively recent nature, the data for internet users is available for a limited number of years, which affects the number of observations in the models that use this variable.

All monetary variables were converted into real terms using the CPI. Details about the variables and related summary statistics are in Table 1 . Table 2 provides simple correlations between the key variables. The table shows that the correlations between most of the variables are modest. Further, relatively speaking, newspaper competition variables (i.e., LclNews and NatNews) have a higher correlation with CORR, than the newspaper diffusion variables (LclReader, NatReader). The formal analysis will reveal the strength of these relations when other relevant factors have been accounted for.

Table 1. Variable definitions, summary statistics and data sources.

\begin{tabular}{|c|c|c|}
\hline Variable & Definition (mean; standard deviation) & Source \\
\hline CORR & $\begin{array}{l}\text { Regional corruption prosecutions per capita }(0.001 \text {; } \\
0.0005)\end{array}$ & Statistiche Giudiziarie \\
\hline BloodDON & $\begin{array}{l}\text { Blood donors - number of registered members AVIS, per } \\
\text { capita }(0.014 ; 0.009)\end{array}$ & $\begin{array}{l}\text { AVIS uniti per la crescita associativa. A cura della Commissione Verifica Poteri } \\
\text { Nazionali. 2011: http://www.avis.it/Statistiche/7/ }\end{array}$ \\
\hline Voters & $\begin{array}{l}\text { Voter turnout (voters/voting-eligible population), (0.80; } \\
\text { 0.09) }\end{array}$ & Ministero dell'interno - Archivio Storico delle Elezioni \\
\hline LcINews & Number of regional newspapers $(2.46 ; 1.79)$ & Accertamenti Diffusione Stampa \\
\hline NatNews & Number of national newspapers $(14.55 ; 1.62)$ & Accertamenti Diffusione Stampa \\
\hline LcIReader & $\begin{array}{l}\text { Regional circulation of regional newspapers per capita } \\
(0.03 ; 0.03)\end{array}$ & Accertamenti Diffusione Stampa \\
\hline NatReader & $\begin{array}{l}\text { Regional circulation of national newspapers per capita } \\
\quad(0.04 ; 0.02)\end{array}$ & Accertamenti Diffusione Stampa \\
\hline Internet & Internet users per 100 population $(20.22 ; 18.59)$ & World Bank, World Development Indicators \\
\hline POP & Regional population $(3,139,308 ; 2,239,254)$ & Istat - Sistema di Indicatori Territoriali. http://sitis.istat.it/sitis/html/ \\
\hline GDP & $\begin{array}{l}\text { Regional real GDP per capita, mill. Euros (base }=1998) \text {, } \\
(0.0002 ; 0.00004)\end{array}$ & Istat - Conti Economici Regionali \\
\hline GovtSize & Government size: Public consumption/GDP $(0.10 ; 0.14)$ & Istat- Bilanci consuntivi delle regioni e province autonome \\
\hline RomaKM & Distance of regional capital from Rome $(424.96 ; 231.44)$ & Google.com \\
\hline
\end{tabular}

Notes: All data are annual by Italian regions, except Internet which is aggregate. The data cover the years 1980-2010 and include 18 regions.

\footnotetext{
${ }^{12}$ The POP determinant is excluded in regressions where all the variables are in per-capita terms.

${ }^{13}$ We are not able to include Trentino-Alto Adige and Valle d'Aosta because of missing data.
} 
Table 2. Correlation matrix of key variables.

\begin{tabular}{lrcrrrrr}
\hline & CORR & BloodDON & Voters & LcINews & NatNews & LclReader & NatReader \\
\hline CORR & 1.00 & & & & & & \\
BloodDON & -0.19 & 1.00 & & & & & \\
Voters & -0.55 & 0.16 & 1.00 & & & & \\
LcINews & -0.28 & 0.59 & 0.24 & 1.00 & & & \\
NatNews & 0.34 & 0.14 & -0.19 & 0.05 & 1.00 & & \\
LclReader & -0.27 & 0.28 & 0.38 & 0.55 & -0.04 & 1.00 & 1.00 \\
NatReader & -0.03 & 0.15 & 0.23 & 0.20 & -0.01 & 0.05 & -0.05 \\
Internet & 0.48 & 0.29 & -0.78 & 0.11 & 0.34 & -0.13 & 1.00 \\
\hline
\end{tabular}

$\mathrm{N}=311$

\section{Estimation}

Given the multidimensional nature of corruption, we account for possible simultaneity issues by estimating Arellano-Bond dynamic panel regressions with maximum 2 lags of the dependent variable and 3 lags of the regressors used as additional instruments. The Wald chi ${ }^{2}$ is statistically significant in all cases, while the number of observations varies across models somewhat due to missing data.

\section{Results}

The dynamic panel estimation results are reported in Table 3-5. In all cases the lagged dependent variable is positive and significant, signifying that there is persistence in corruption and its exposure. In other results, the effects of population are positive, government size is negative and economic prosperity (GDP) is statistically insignificant in all cases. The influence of population is consistent with greater corruption exposure in larger regions (maybe due to greater awareness, networking, etc.), while the (negative) effect of government size is consistent with the difficulties in exposing large, complex governments. With regard to the broader corruption determinants literature, press freedom and internet discussion have been shown to decrease corruption, while the effects of government size are mixed (see Dimant and Tosato (2018)). ${ }^{14}$

We turn next to specific issues to address the questions in the introduction.

\section{Media competition and corruption exposure}

Table 3, Model 3.2, focuses on the effects of media competition on corruption exposure, making the distinction between national and local or
Table 3. Civic activism and exposed corruption: Baseline models (Dependent variable: CORR).

\begin{tabular}{|c|c|c|c|}
\hline & 3.1 & 3.2 & 3.3 \\
\hline CORR-1 & $\begin{array}{c}0.44^{* *} \\
(3.8)\end{array}$ & $\begin{array}{c}0.41^{* *} \\
(3.5)\end{array}$ & $\begin{array}{c}0.45^{* *} \\
(3.9)\end{array}$ \\
\hline GDP & $\begin{array}{l}4.67 \\
(1.3)\end{array}$ & $\begin{array}{l}0.24 \\
(0.1)\end{array}$ & $\begin{array}{l}5.45 \\
(1.5)\end{array}$ \\
\hline GovtSize & $\begin{array}{c}-0.0001^{* *} \\
(3.4)\end{array}$ & $\begin{array}{c}-0.0001^{* *} \\
(3.6)\end{array}$ & $\begin{array}{c}-0.0001^{* *} \\
(2.1)\end{array}$ \\
\hline Internet & $\begin{array}{c}-9.05 \mathrm{e}-06^{* *} \\
(2.5)\end{array}$ & $\begin{array}{c}-6.28 \mathrm{e}-06 \\
(1.4)\end{array}$ & $\begin{array}{c}-7.00 \mathrm{e}-06^{*} \\
(1.8)\end{array}$ \\
\hline POP & $\begin{array}{c}1.82 \mathrm{e}-09^{* *} \\
(2.5)\end{array}$ & $\begin{array}{c}1.86 \mathrm{e}-09^{* *} \\
(2.4)\end{array}$ & $\begin{array}{c}2.06 \mathrm{e}-09^{* *} \\
(2.6)\end{array}$ \\
\hline BloodDON & $\begin{array}{c}0.10^{* *} \\
(4.6)\end{array}$ & $\begin{array}{c}0.11^{* *} \\
(4.9)\end{array}$ & $\begin{array}{c}0.08^{* *} \\
(3.9)\end{array}$ \\
\hline Voters & $\begin{array}{c}0.002^{* *} \\
(3.4)\end{array}$ & $\begin{array}{c}0.002^{* *} \\
(3.4)\end{array}$ & $\begin{array}{c}0.002^{* *} \\
(3.5)\end{array}$ \\
\hline LcINews & & $\begin{array}{c}-0.0002^{*} \\
(1.9)\end{array}$ & \\
\hline NatNews & & $\begin{array}{c}-7.24 \mathrm{e}-06 \\
(0.6)\end{array}$ & \\
\hline LclReader & & & $\begin{array}{c}-0.007^{* *} \\
(4.4)\end{array}$ \\
\hline NatReader & & & $\begin{array}{c}0.02^{* *} \\
(2.1)\end{array}$ \\
\hline $\mathrm{N}$ & 296 & 295 & 296 \\
\hline Wald $c h i^{2}$ & $449.6^{* *}$ & $521.7^{* *}$ & $580.7^{* *}$ \\
\hline AR1 test (p-value) & 0.009 & 0.01 & 0.02 \\
\hline AR2 test ( $p$-value) & 0.24 & 0.32 & 0.12 \\
\hline \multicolumn{4}{|c|}{$\begin{array}{l}\text { Notes: Notes: See Table } 1 \text { for variable details. Constant included but no } \\
\text { reported in these Arellano-Bond dynamic panel regressions with max } \\
\text { imum } 2 \text { lags of the dependent variable and } 3 \text { lags of the regressors usec } \\
\text { as additional instruments. CORR-1 denotes the lagged value of CORR } \\
\text { The numbers in parentheses are z-statistics based on robust standarc } \\
\text { errors, with * and **, respectively, denoting statistical significance at the } \\
10 \% \text { and } 5 \% \text { (or better) levels. }\end{array}$} \\
\hline
\end{tabular}

regional newspapers. The time series nature of our data enables us to track entry and exit of newspapers both at the national and the regional levels (see Drago, Nannicini, and Sobbrio (2014), Petrarca (2014)).

Results show that the effects of both local and national newspaper competition to be negative, with the impact of national competition being statistically insignificant. These results consistently hold across all the models estimated in Tables 4 and 5 as well. The negative impact of local newspaper competition on corruption exposure can be

\footnotetext{
${ }^{14} \mathrm{~A}$ distinction with the literature is that we are uniquely considering various civic activism effects on corruption exposure for Italian regions.
} 
Table 4. Civic activism and exposed corruption: Additional considerations (Dependent variable: CORR).

\begin{tabular}{|c|c|c|}
\hline & 4.1 & 4.2 \\
\hline CORR-1 & $\begin{array}{c}0.41^{* *} \\
(3.5)\end{array}$ & $\begin{array}{c}0.45^{* *} \\
(3.9)\end{array}$ \\
\hline GDP & $\begin{array}{l}0.24 \\
(0.1)\end{array}$ & $\begin{array}{l}5.45 \\
(1.5)\end{array}$ \\
\hline GovtSize & $\begin{array}{c}-0.0001^{* *} \\
(3.6)\end{array}$ & $\begin{array}{c}-0.0001^{* *} \\
(2.1)\end{array}$ \\
\hline Internet & $\begin{array}{c}-6.28 \mathrm{e}-06 \\
(1.4)\end{array}$ & $\begin{array}{c}-7.00 \mathrm{e}-06^{*} \\
(1.8)\end{array}$ \\
\hline POP & $\begin{array}{c}1.86 \mathrm{e}-09^{* * *} \\
(2.4)\end{array}$ & $\begin{array}{c}2.06 \mathrm{e}-09^{* *} \\
(2.6)\end{array}$ \\
\hline BloodDON & $\begin{array}{c}0.11^{* *} \\
(4.9)\end{array}$ & $\begin{array}{c}0.08^{* *} \\
(3.9)\end{array}$ \\
\hline Voters & $\begin{array}{c}0.002^{* *} \\
(3.4)\end{array}$ & $\begin{array}{c}0.002^{* *} \\
(3.5)\end{array}$ \\
\hline LcINews & $\begin{array}{c}-0.0002^{*} \\
(1.9)\end{array}$ & \\
\hline NatNews & $\begin{array}{c}-7.24 \mathrm{e}-06 \\
(0.6)\end{array}$ & \\
\hline LcIReader & & $\begin{array}{c}-0.007^{* *} \\
(4.4)\end{array}$ \\
\hline NatReader & & $\begin{array}{c}0.02^{* *} \\
(2.1)\end{array}$ \\
\hline RomaKM & $\begin{array}{c}-0.00002^{* *} \\
(3.1)\end{array}$ & $\begin{array}{c}-0.00003^{* * *} \\
(2.9)\end{array}$ \\
\hline $\mathrm{N}$ & 295 & 296 \\
\hline Wald $c h i^{2}$ & $471.1^{* *}$ & $505.6^{* *}$ \\
\hline
\end{tabular}

Notes: See Table 3.

Table 5. Civic activism and exposed corruption: Effect of Mani Pulite (Dependent variable: CORR).

\begin{tabular}{lcc}
\hline & 5.1 & 5.2 \\
\hline CORR-1 & $0.38^{* *}$ & $0.45^{* *}$ \\
GDP & $(3.0)$ & $(3.5)$ \\
& -1.86 & 3.53 \\
GovtSize & $(1.2)$ & $(0.9)$ \\
& $-0.0001^{* *}$ & $-0.0001^{* *}$ \\
Internet & $(3.8)$ & $(2.5)$ \\
& $-3.36 \mathrm{e}-06$ & $-4.27 \mathrm{e}-06$ \\
POP & $(0.7)$ & $(1.2)$ \\
& $1.84 \mathrm{e}-09^{* *}$ & $1.95 \mathrm{e}-09^{* *}$ \\
BloodDON & $(2.3)$ & $(2.6)$ \\
& $0.11^{* *}$ & $0.08^{* *}$ \\
Voters & $(3.9)$ & $(3.2)$ \\
& $0.002^{* *}$ & $0.002^{* *}$ \\
LcINews & $(4.0)$ & $(3.4)$ \\
& $-0.0002^{*}$ & \\
NatNews & $(1.8)$ & \\
& $-7.95 \mathrm{e}-06$ & \\
LclReader & $(0.4)$ & $-0.007^{* *}$ \\
& & $(3.6)$ \\
NatReader & & $0.02^{* *}$ \\
& & $(2.0)$ \\
$\mathrm{N}$ & & 238 \\
Wald chi ${ }^{2}$ & 237 & $645.4^{* *}$ \\
\hline
\end{tabular}

Notes: See Table 3.

seen as consistent with the notion of a greater chance of media capture (i.e., avoidance of corruption exposure) at the local level. Alternately, if the threat of greater media presence reduces corruption, then the consequent exposure would also go down. Further, the effects of newspaper competition and the internet appear to be complementary.

\section{Media diffusion and corruption exposure}

Model 3.3 takes a different angle by considering the effects of media diffusion (see Reinikka and Svensson (2005)). This may be viewed as the effectiveness of media since it captures newspaper usage/readership and how that might impact corruption exposure.

The corresponding results show an interesting contrast between local and national newspaper diffusion, with both effects being statistically significant. In particular, the effects of LclReader are negative, suggesting greater diffusion of local newspapers, in fact, reduce corruption exposure, while national newspaper diffusion heightens corruption exposure. This may be due to greater local diffusion diluting the urgency of individual corruption cases or greater possibilities of media capture at the local level whereby some corruption scandals are either not exposed or underexposed (see Besley and Prat (2006), Camaj (2013), Di Tella and Franceschelli (2011), Djankov et al. (2003)). This revelation seems unique to the present work.

\section{Effects of the internet}

The effect of the internet on corruption exposure is negative in all cases, with the statistical significance varying across the various models. The negative effect can be present when the internet empowers both the perpetrators and exposures of corruption and when the perpetrators are more effectively able to counter the charges against them (via misinformation, blog posts, etc.). This might also have to do with the technological changes in the internet uses over time affecting both the demand and supply during the sample period (e.g., the evolution of the smartphones, the decline in the digital divide, the meshing of physical and online newspapers, etc.). ${ }^{15}$

\section{Effect of other forms of civic activism}

Turning to the impact of civic activism, we see that greater activism, whether measured by the number

\footnotetext{
${ }^{15}$ Goel, Nelson, and Naretta (2012) have considered an alternate dimension where the internet has been shown to enhance corruption awareness.
} 
of blood donors or via voter turnout, has a positive impact on corruption exposure. ${ }^{16}$ A zealous or involved populace facilitates the prosecution of corruption cases. The actions of activists might provide both actual and latent inducements to exposing corruption. As a way of latent inducement, an activist populace makes the law enforcement machinery more vigilant. The relative efficacy of the all civic activism measures is evaluated in the next section.

\section{Relative magnitudes of impacts}

To obtain further insights into the relative impacts of the media, internet, and civic activism, it seems useful to consider their relative magnitudes. Focusing on Model 3.3 and examining the elasticities evaluated at respective means, ${ }^{17}$ we find that $\varepsilon$ CORR, Internet $=-0.14 ; \varepsilon$ CORR, BloodDON $=1.12 ; \varepsilon$ CORR, Voters $=1.6 ; \varepsilon$ CORR, LclReader $=-0.21$; and $\varepsilon$ CORR, NatReader $=0.8$.

The following main points emerge from these quantitative comparisons: (i) the elasticities with respect to the two civic activism measures are elastic, while all the others are inelastic; (ii) corruption exposure has the lowest relative responsiveness to the internet (in absolute value); (iii) corruption exposure has the greatest responsiveness with regard to voter turnout, with double the responsiveness with regard to national newspaper diffusion (NatReader); (iv) in terms of absolute magnitudes, the responsiveness of corruption exposure to national newspaper diffusion is about four times as great as that with regard to local newspaper diffusion; and (v) the elasticity with respect to voter turnout is greater than that with regard to blood donors. These findings, besides providing unique quantitative insights have obvious policy implications.

Thus, we find some support for Hypothesis 1 in that the active activism, especially in the form of voter turnout, has a larger impact on corruption exposure than passive activism in the form of blood donors.

\section{Additional consideration 1: geographic effects}

Table 4 accounts for geographic influences by considering for the location of the nation's capital,
Rome. Geographic factors in the context of corruption have been deemed relevant in other contexts (Goel and Nelson $(2010,2011))$. On the one hand, there are greater corruption cases with a greater potential disbursement of discretionary favors around the nation's capital; on the other hand, media scrutiny would be disproportionately greater in the vicinity of the capital.

We account for Rome's location by including a variable, RomaKM, that measures the distance of Rome from the regional capital. The resulting coefficient is negative and statistically significant in both models in Table 4 (bear in mind, however, that RomaKM does not vary over time other results from Tables 3 and 4 are quite similar). This is consistent with the notion that regions farther away from the capital would have lower corruption exposure, ceteris paribus. The results for the other variables are quite similar to what was reported in Table 3.

\section{Additional consideration2: effect of Mani Pulite}

In Table 5 we consider the effects of Mani Pulite or 'clean hands' policy by considering the sample from 1993 onwards. Mani Pulite was a significant institutional change in government attitude towards corruption by adopting a more aggressive approach to corruption control. This post-1992 subsample reinforces the earlier findings about the effects of media and civic activism. Interestingly, however, the effects of the internet, while still negative, are now statistically insignificant. This makes sense when one thinks about the fact that, during the latter part of the nineties, the distinction between the internet and the (physical) newspapers was becoming somewhat blurred with many newspapers having their online versions.

Another way to examine the influence of Mani Pulite might be to examine the magnitude of the effect of the government size (GovtSize) variable. Keeping in mind that we measure government size broadly via the share of government consumption in regional GDP that masks many qualitative aspects, the coefficient on GovtSize has the same magnitude across different models in Table 3-5.

\footnotetext{
${ }^{16} \mathrm{At}$ a finer level of detail, the personal (transactions) costs associated with blood donation are somewhat higher than those with voting.

${ }^{17}$ Given the statistical insignificance of NatNews (Model 3.2) which makes the comparison with LcINews less relevant, we do not consider NatNews and LcINews.
} 
Thus, based on this consideration, Mani Pulite does not seem to have improved government effectiveness with regard to corruption control.

Overall, we are able to show the relative efficacy of different forms of civic activism in exposing corruption. The concluding section follows.

\section{Discussion and conclusions}

This article adds to the literature on media and corruption by examining the effects of civic activism on corruption exposure. Given difficulties with capturing the true extent of corruption, we take the available corruption prosecutions across Italian regions to denote corruption exposure. While the media-corruption nexus has attracted attention in the literature (see Brunetti and Weder (2003), Camaj (2013), Freille, Haque, and Kneller (2007), Vaidya (2005)), some of the aspects examined in this study are unique not only to the Italian context but also to the broader literature on corruption determinants. The extant literature generally uses composite indices to capture media freedom (e.g., Chowdhury (2004)). We are able to address media competition and its impact using more direct national and regional measures. Relatively less attention has been paid to the role civic activism can play and we consider various dimensions.

Results address the questions posed in the introduction.

- What is the effect of policy pertaining to the impact of civic activism on corruption exposure? The answer depends on the media type. For instance, the effects of media competition are opposite to those of other forms of civic activism. While greater activism in the form of voter turnout and blood donors enhances corruption exposure, greater media competition, especially local media competition (and the internet), reduces corruption exposure. Thus, we are able to highlight the differences in the impacts of local and national media. The issue of newspaper entry and diffusion for Italy has been studied elsewhere (Drago, Nannicini, and Sobbrio (2014), Petrarca (2014)), but not in regard to its impact on corruption.

- Are the influences of activist activism the same as those of passive activism?
Depends. While some forms of activist activism in the form of voter turnout has a qualitatively similar effect in exposing corruption as the passive activism in the form of blood donors, other forms of activism like the internet and local newspapers have opposite influences.

- Are the effects of newspapers and the internet similar in terms of exposing corruption?

Yes and no. The (negative) effects of internet diffusion are more aligned with those of local newspapers, both their competition and diffusion. However, statistical support for the effect of the internet varies. The examination of relative impacts of the internet and newspapers on Italian subnational corruption appears unique in the literature.

- Do regional and national newspapers have similar effects on corruption exposure?

No. Local newspapers, both their circulation and competition, lower corruption exposure, while national circulation increases it. National newspaper competition, on the other hand, has no significant impact.

These findings have some import for media policy pertaining to the impact on corruption. We see that the geographic scope of the media and the type of media matter. We find that regionalnational differences matter in terms of their impacts on exposing corruption, with the potential of media capture greater at the local level. On the other hand, freedom of entry of newspapers would aid in corruption exposure, especially at the national level. The effects of the internet were mixed, partly reflecting changing technologies that have affected the applications and synergies with newspapers over time. Further, the limited ability of lawmakers to police new technologies like the internet undermines the abilities of nation states.

An interesting and novel finding is that, rather than focusing on the role of the media, encouragement of specific forms of civic activism might yield greater mileage in terms of corruption exposure. This issue needs to be studied in more detail in a cross-country context, where nations differ significantly in the free$\operatorname{dom}(\mathrm{s})$ they allow their citizens.

The persistence in corruption/corruption exposure calls for long-term policy consistency in combating corruption. This suggests that there are 
likely networks in activism that form in exposing corruption and there is some inertia in these. In other implications, a larger government, while traditionally related to creating bureaucratic red tape (Rose-Ackerman (1999)), might, in fact, reduce corruption exposure, while regions farther from a nation's seat of government face special challenges in exposing corruption (Table 4).

Finally, the larger issue of how adequately to capture the extent of corrupt activity remains a challenge for policymakers (and for researchers). A reader familiar with the broader corruption literature would notice that what we call corruption exposure, has routinely been used as corruption (see, for example, Goel and Nelson (2011)), with the underlying assumption being that there is no measurement error and all corrupt activity is detected and prosecuted. If one takes that interpretation, the results are consistent with some causes and influences of corruption (again, due to the multidimensional nature of corrupt activities). For instance, with regard to the activism measures and taking our measure CORR to denote the level of corruption, we would then interpret that there is corruption in Italy associated with voter turnouts, blood donations (i.e., the hospital sector), and with national media, while local media and the internet mitigate these effects via exposure of corrupt acts. Again, the main point about the varying effectiveness of various forms of activism holds. Of course, these findings based on Italian data could benefit from validation from similar studies of other nations.

\section{Acknowledgments}

We thank a referee, Toke Aidt and participants at the 14th PEARL workshop, the 2018 European Public Choice Society meetings and the CESifo Conference on the Economics of Digitization for useful comments on earlier versions. Goel thanks the Department of Social and Economic Sciences - Sapienza University of Rome for providing a productive environment during a research visit.

\section{Disclosure statement}

No potential conflict of interest was reported by the authors.

\section{References}

ADS (Accertamenti Diffusione Stampa). Cronos, Various Years. Milano. Milano: ADS Notizie.

Agostino, D. 2013. "Using Social Media to Engage Citizens: A Study of Italian Municipalities." Public Relations Review 39: 232-234.

Aidt, T. S. 2003. "Economic Analysis of Corruption: A Survey." The Economic Journal 113: F632-F652.

Andersen, T. B. 2009. "E-Government as an Anti-Corruption Strategy." Information Economics and Policy 21: 201-210.

Belousova, V., R. K. Goel, and I. Korhonen. 2016. "Corruption Perceptions versus Corruption Experience: Competition for Rents across Russian Regions." Journal of Economics and Finance 40: 172-187.

Bertot, J. C., P. T. Jaeger, and J. M. Grimes. 2010. "Using ICTs to Create a Culture of Transparency: E-Government and Social Media as Openness and Anti-Corruption Tools for Societies." Government Information Quarterly 27: 264-271.

Bertrand, M., and S. Mullainathan. 2001. "Do People Mean What They Say? Implications for Subjective Survey Data." American Economic Review, AEA Papers and Proceedings 91: 67-72.

Besley, T., and A. Prat. 2006. "Handcuffs for the Grabbing Hand? Media Capture and Government Accountability." American Economic Review 96: 720-736.

Bhattacharyya, S., and R. Hodler. 2015. "Media Freedom and Democracy in the Fight against Corruption." European Journal of Political Economy 39: 13-24.

Brunetti, A., and B. Weder. 2003. "A Free Press Is Bad News for Corruption.” Journal of Public Economics 87: 1801-1824.

Camaj, L. 2013. “The Media's Role in Fighting Corruption: Media Effects on Governmental Accountability." International Journal of Press/Politics 18: 21-42.

Campante, F. R., and Q.-A. Do. 2014. "Isolated Capital Cities, Accountability, and Corruption: Evidence from US States." American Economic Review 104: 2456-2481.

Chowdhury, S. K. 2004. "The Effect of Democracy and Press Freedom on Corruption: An Empirical Test." Economic Letters 85: 93-101.

Corrado, G., and F. Rossetti. 2018. "Public Corruption: A Study across Regions in Italy." Journal of Policy Modeling in press.

Del Monte, A., and E. Papagni. 2007. "The Determinants of Corruption in Italy: Regional Panel Data Analysis." European Journal of Political Economy 23: 379-396.

Della Porta, D., and A. Vannucci. 2007. "Corruption and Anti-Corruption: The Political Defeat of 'Clean Hands' in Italy.” West European Politics 30: 830-853.

Di Tella, R., and I. Franceschelli. 2011. "Government Advertising and Media Coverage of Corruption Scandals." American Economic Journal: Applied Economics 3: 119-151.

Di Vita, G. 2011. "Curbing Corruption in Public Administration: A Case Study from Italy." International Journal of Public Administration 34: 631-645. 
Dimant, E., and G. Tosato. 2018. "Causes and Effects of Corruption: What Has past Decade's Empirical Research Taught Us? A Survey." Journal of Economic Surveys 32: 335-356.

Djankov, S., C. McLiesh, T. Nenova, and A. Shleifer. 2003. "Who Owns the Media?" Journal of Law and Economics 46: 341-381.

Donchev, D., and G. Ujhelyi. 2014. "What Do Corruption Indices Measure?" Economics \& Politics 26: 309-331.

Drago, F., T. Nannicini, and F. Sobbrio. 2014. "Meet the Press: How Voters and Politicians Respond to Newspaper Entry and Exit." American Economic Journal: Applied Economics 6: 159-188.

Freille, S., M. E. Haque, and R. Kneller. 2007. "A Contribution to the Empirics of Press Freedom and Corruption." European Journal of Political Economy 23: 838-862.

Goel, R. K., J. Budak, and E. Rajh. 2013. "Bureaucratic Monopoly and the Nature and Timing of Bribes: Evidence from Croatian Data." Comparative Economic Studies 55: 43-58.

Goel, R. K., and M. A. Nelson. 2010. "Causes of Corruption: History, Geography and Government." Journal of Policy Modeling 32: 433-447.

Goel, R. K., and M. A. Nelson. 2011. "Measures of Corruption and Determinants of U.S Corruption." Economics of Governance 12: 155-176.

Goel, R. K., and M. A. Nelson. 2014. "Whistleblower Laws and Exposed Corruption in the United States." Applied Economics 46: 2331-2341.

Goel, R. K., M. A. Nelson, and M. A. Naretta. 2012. "The Internet as an Indicator of Corruption Awareness." European Journal of Political Economy 28: 64-75.

Golden, M. A., and L. Picci. 2005. "Proposal for a New Measure of Corruption, Illustrated with Italian Data." Economics \& Politics 17: 37-75.

Istat. 1980-2010. Bilanci Consuntivi Delle Regioni E Delle Province Autonome. Roma: Istat.

Istat. Statistiche Giudiziarie. various years, Roma: Istat.

Istat. Conti Regionali. various years, Roma: Istat.

Kalenborn, C., and C. Lessmann. 2013. "The Impact of Democracy and Press Freedom on Corruption: Conditionality Matters." Journal of Policy Modeling 35: 857-886.

Lambsdorff, J. G. 2006. "Causes and Consequences of Corruption: What Do We Know from a Cross-Section of Countries?" In International Handbook on the Economics of Corruption, edited by S. Rose-Ackerman, 3-51. Cheltenham U.K.: Edward Elgar.

Ministero dell'Interno. Archivio Storico Delle Elezioni. various years Roma.
Mullainathan, S., and A. Shleifer. 2005. "The Market for News." American Economic Review 95: 1031-1053.

Olken, B. A. 2009. "Corruption Perceptions Vs. Corruption Reality." Journal of Public Economics 93: 950-964.

Paldam, M. 2002. "The Cross-Country Pattern of Corruption: Economics, Culture and the Seesaw Dynamics." European Journal of Political Economy 18: 215-240.

Petrarca, I. 2014. "No News Is Costly News: The Link between the Diffusion of the Press and Public Spending." European Journal of Political Economy 34: 68-85.

Petrarca, I., and R. Ricciuti. 2013. "The Historical Economics of Corruption and Development within Italy." International Journal of Monetary Economics and Finance 6: $186-210$.

Picci, L. 2006. "Reputation-Based Governance of Public Works." Rivista Di Politica Economica 96: 161-184.

Priks, M. 2011. "Judiciaries in Corrupt Societies." Economics of Governance 12: 75-88.

Reinikka, R., and J. Svensson. 2005. "Fighting Corruption to Improve Schooling: Evidence from a Newspaper Campaign in Uganda." Journal of the European Economic Association 3: 259-267.

Rhodes, M. 1997. "Financing Party Politics in Italy: A Case of Systemic Corruption.” West European Politics 20: 54-80.

Rizzica, L., and M. Tonello, 2016. Exposure to Media and Corruption Perceptions. Bank of Italy Temi di Discussione (Working Paper). No. 1043.

Rose-Ackerman, S. 1999. Corruption and Government. Cambridge U.K: Cambridge University Press.

Seldadyo, H., and J. De Haan, 2006. The Determinants of Corruption: A Literature Survey and New Evidence. Paper presented at European Public Choice Society Meetings, Turku.

Serra, D. 2006. "Empirical Determinants of Corruption: A Sensitivity Analysis.” Public Choice 126: 225-256.

Shleifer, A., and R. W. Vishny. 1993. "Corruption.” Quarterly Journal of Economics 108: 599-617.

Svensson, J. 2005. "Eight Questions about Corruption." Journal of Economic Perspectives 19: 19-42.

Treisman, D. 2000. "The Causes of Corruption: A CrossNational Study.” Journal of Public Economics 76: 399-457.

Vaidya, S. 2005. "Corruption in the Media's Gaze." European Journal of Political Economy 21: 667-687.

Valentini, E. 2012. Dalle Gazzette all'iPad. Il Giornalismo Al Tempo Dei Tablet. Milano: Modadori Università.

World Bank. World Development Indicators, various years

Yang, G. 2009. “Online Activism.” Journal of Democracy 20 (3): $33-36$ 